\title{
Pelatihan Pengelolaan Pembukuan Dan Pelaporan Keuangan Bagi Pelaku UMKM Di Desa Kutakarya Karawang
}

\author{
Evi Selvi \\ Fakultas Ekonomi dan Bisnis, Universitas Singaperbangsa Karawang
}

\begin{abstract}
ABSTRAK
Kurangnya pengetahuan dan informasi pasar serta rendahnya kompetensi SDM para pelaku UMKM di Kabupaten Karawang, menjadi salah satu kelemahan UMKM, sebagaimana dikatakan Kepala Dinas Perindustrian, Perdagangan, Pertambangan dan Energi setempat, "Itu hanya salah satu kendala, masih ada permasalahan atau kelemahan UMKM lainnya yang cukup menghambat pengembangan UMKM di Karawang," Menurut Kepala Dinas Perisdustrian Perdagangan Kabupeten Karawang, permasalahan lain yang menjadi kendala dalam mengembangkan UMKM di Karawang ialah rendahnya jiwa kewirausahaan para pelaku UMKM dan aksebilitas terhadap sumber permodalan yang masih rendah. Para pelaku UMKM di Karawang, lebih lanjut kepala dinas perindustrian mengatakan disamping kendala tersebut diatas kendala lain adalah UMKM belum mampu menjalin kemitraan secara baik kepada industri besar, serta pelaku UMKM belum mampu menghasilkan produk yang berkualitas.Sehingga dampak dari permasalahan dan kelemahan tersebut, produk-produk UMKM di Karawang belum memiliki daya saing di pasaran. Sehubungan dengan permasalahan lemahnya pemasaran produk UMKM di Karawang dan bagi para konsumen saya harapkan dapat menerima atau mengkonsumsi produk produk hasil UMKM dari Karawang, sehingga diharapkan dengan meningkatnya omset penjualan maka para pelaku UMKM juga dapat melakukan penambahan investasi untuk memperbaiki qualitas maupun kuantitas dari produk yang mereka hasilkan, sehingga dimasa yang akan datang hasil produk dari para UMKM di Karawang dapat bersaing dengan produk produk luar kota maupun luar negeri.
\end{abstract}

Kata kunci : UMKM, Pasar

\begin{abstract}
The lack of market knowledge and information as well as the low competency of SDM actors in Karawang Regency are one of the weaknesses of UMKM, as said by the Head of the local Industry, Trade, Mining and Energy Office, "That is only one of the obstacles, there are still problems or weaknesses of other UMKM that can be overcome enough to hinder the development of UMKM in Karawang," According to the Head of the Department of Industry and Trade, Karawang Regency, another problem that becomes an obstacle in developing UMKM in Karawang is the low entrepreneurial spirit of UMKM actors and accessibility to sources of capital which is still low. The UMKM actors in Karawang, furthermore, the head of the industry office said that in addition to the constraints mentioned above, another obstacle was that UMKM had not been able to establish good partnerships with large industries, and UMKM actors had not been able to produce quality products. UMKM products in Karawang do not yet have competitiveness in the market. In connection with the problem of weak marketing of UMKM products in Karawang and for consumers I hope to be able to receive or consume UMKM products from Karawang, so it is hoped that with increased sales turnover, UMKM actors can also make additional investments to improve the quality and quantity of their products. produce, so that in the future the products of UMKM in Karawang can compete with products from outside the city and abroad.
\end{abstract}

Keywords: UMKM, Market 


\section{PENDAHULUAN}

Usaha kecil dan menengah (UKM) di berbagai negara termasuk di Indonesia merupakan salah satu penggerak perekonomian rakyat yang tangguh. Hal ini karena kebanyakan para pengusaha kecil dan menengah berangkat dari industri keluarga/ rumahan. Dengan demikian konsumennya pun berasal dari kalangan menengah ke bawah. Selain itu, Peranan UKM terutama sejak krisis moneter tahun 1998 dapat dipandang sebagai katup penyelamat dalam proses pemulihan ekonomi nasional, baik dalam mendorong laju pertumbuhan ekonomi maupun penyerapan tenaga kerja.

Kinerja UKM dalam beberapa tahun terakhir menunjukkan peningkatan. Data Badan Pusat Statistik (BPS) menunjukkan besaran Produk Domestik Bruto yang diciptakan UKM dalam tahun 2003 mencapai nilai Rp 1.013,5 triliun (56,7 persen dari PDB). Jumlah unit usaha UKM pada tahun 2003 mencapai 42,4 juta, sedangkan jumlah tenaga kerja yang bekerja di sektor ini tercatat 79,0 juta pekerja. Pertumbuhan PDB UKM periode 2000 2003 ternyata lebih tinggi daripada total PDB, yang sumbangan pertumbuhannya lebih besar dibandingkan dengan Usaha Besar. ${ }^{[1]}$

Perkembangan sektor UKM yang demikian menyiratkan bahwa terdapat potensi yang besar jika hal ini dapat dikelola dan dikembangkan dengan baik tentu akan dapat mewujudkan usaha menengah yang tangguh. Sementara itu, disisi yang lain UKM juga masih dihadapkan pada masalah yang terletak pada proses administrasi. Pemerintah sudah mencoba membantu mengatasi kendala yang dihadapi oleh sebagian besar UKM, seperti melakukan pembinaan dan pemberian kredit lunak.

Masalah utama dalam pengembangan UKM di antaranya adalah mengenai pengelolaan keuangan dalam usahanya tersebut, karena pengelolaan yang baik memerlukan keterampilan Akuntansi yang baik pula oleh pelaku bisnis UKM. Padahal dengan adanya laporan keuangan akan memungkinkan pemilik memperoleh data dan informasi yang tersusun secara sistematis. Dengan adanya laporan keuangan, pemilik dapat memperhitungkan keuntungan yang diperoleh, mengetahui berapa tambahan modal yang dicapai, dan juga dapat mengetahui bagaimana keseimbangan hak dan kewajiban yang dimiliki. Sehingga setiap keputusan yang diambil oleh pemilik dalam mengembangkan usahanya akan didasarkan pada kondisi konkret keuangan yang dilaporkan secara lengkap bukan hanya didasarkan pada asumsi semata. 
Berdasarkan realitas tersebut, maka untuk membantu memudahkan pelaku UKM dalam mencatat setiap kegiatan usaha yang terjadi dan menyusun laporan keuangan, penulis memberi judul pelatihan "PERANCANGAN dan PENERAPAN AKUNTANSI PADA UKM".

\section{METODE}

Ada beberapa motoda pelatihan atau training (Marihot Tua Efendi Hariandja 2002:176), yaitu :

1. Job Instruction Training, atau latihan instruksi jabatan adalah penelitian dimana ditentukan seseorang (biasanya manajer/supervisor) bertindak sebagai pelatih untuk mengintruksikan bagaimana melakukan pekerjaan tertentu dalam proses kerja.

Metoda ini bila mana dikaitkan secara khusus dengan prinsip - prinsip belajar diatas terlihat dengan jelas memiliki partisipasi yang tinggi, relevance, repetition, transference, dan juga feedback.

2. Coaching (Pelatihan) adalah bentuk pelatihan dan pengembangan yang dilakukan ditempat kerja oleh atasa dengah membimbing petugas melakukan pekerjaan secara informal dan biasanya tidak terencana, missal bagaimana melakukan pekerjaan, bagaimana memecahkan masalah. Dilihat dari prinsip - prinsip belajar, metode ini mengaplikasikan prinsip belajar partisipasi yang tinggi, relevance, repetition, transference, dan juga feedback.

3. Job rotation (Rotasi Pekerjaan) adalah program yang direncanakan secara formal dengan acara menugaskan pegawai pada beberapa pekerjaan yang berbeda dan bagaimana yang berbeda dengan organisasi untuk menambah pengetahuan mengenai pekerjaan dalam organisasi. Ini biasnya dilakukan untuk pengermbangan pegawai untuk memahami aktivitas organisasi yang lebih luas, bilamana dilihat dari prinsip - prinsip mengaplikasikan hamapir semua prinsip belajar kecuali feedback.

4. Apprenticeship (Masa Magang) adalah pelatih yang mengkombinasikan antara pelajaran dikelas dengan praktek dilapangan, yaitu setelah sejumlah teori diberikan kepada peserta, peserta dibawa praktek kelapangan. Tekhnik ini juga mengaplikasikan seluruh prinsip seperti tersebut diatas. 


\section{HASIL PEMBAHASAN, DAN DAMPAK}

A. Hasil yang di Capai

Berdasarkan hasil observasi dan wawancara mendalam dengan beberapa pengusaha secara acak menunjukkan hasil kegiatan ini sebagai berikut:

1. Meningkatnya pengetahuan dan pemahaman para Pengusaha terhadap perkembangan terkini di bidang perpajakan, khususnya hal-hal yang terkait penyusunan laporan keuangan;

2. Meningkatnya wawasan dan pengalaman pengusaha kecil dan menengah (UKM) dalam mengenal institusi pemerintah di tingkat pusat serta peranan penyusunan laporan keuangan UMKM yang ditempuhnya dalam mendorong roda perekonomian nasional.

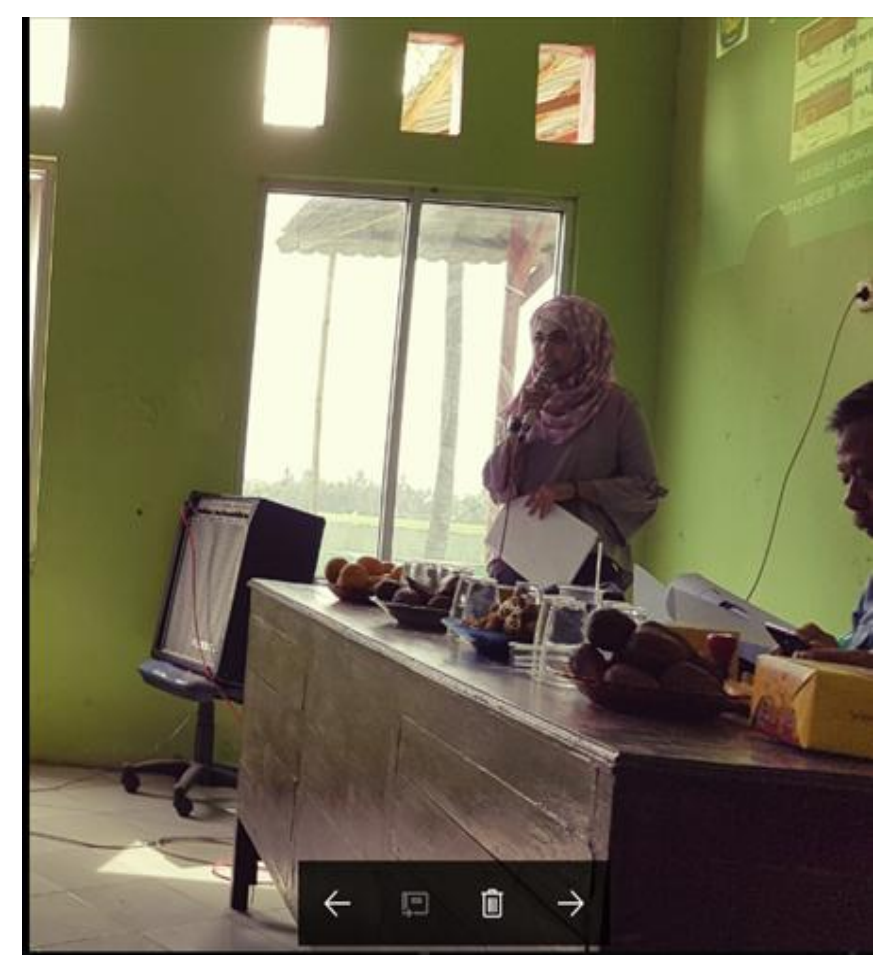

Gambar 1. Foto Kegiatan

B. Faktor Pendukung dan Penghambat

Beberapa faktor yang mendukung terselenggaranya kegiatan ini di antaranya, komunikasi dan kerja sama yang baik dengan Direktorat Jenderal Pajak Kementerian Keuangan. Di samping itu, besarnya antusiasme pengusaha baik dalam keikutsertaan maupun dalam menggali informasi selama kegiatan ini dilangsungkan. Sedangkan faktorfaktor yang menghambat di antaranya ketidakhadiran dan keterlambatan kedatangan 
beberapa pengusahakecil dan menengah di tempat/titik aula pelatihan KPP Karawang Utara.

Selain itu, ketersediaan waktu kunjungan di Direktorat Jenderal Pajak yang terbatas menyebabkan waktu penyelenggaraan sosialisasi tidak terasa cepat berlalu, sementara para pengusahamasih antusias melakukan tanya jawab dengan para narasumber.

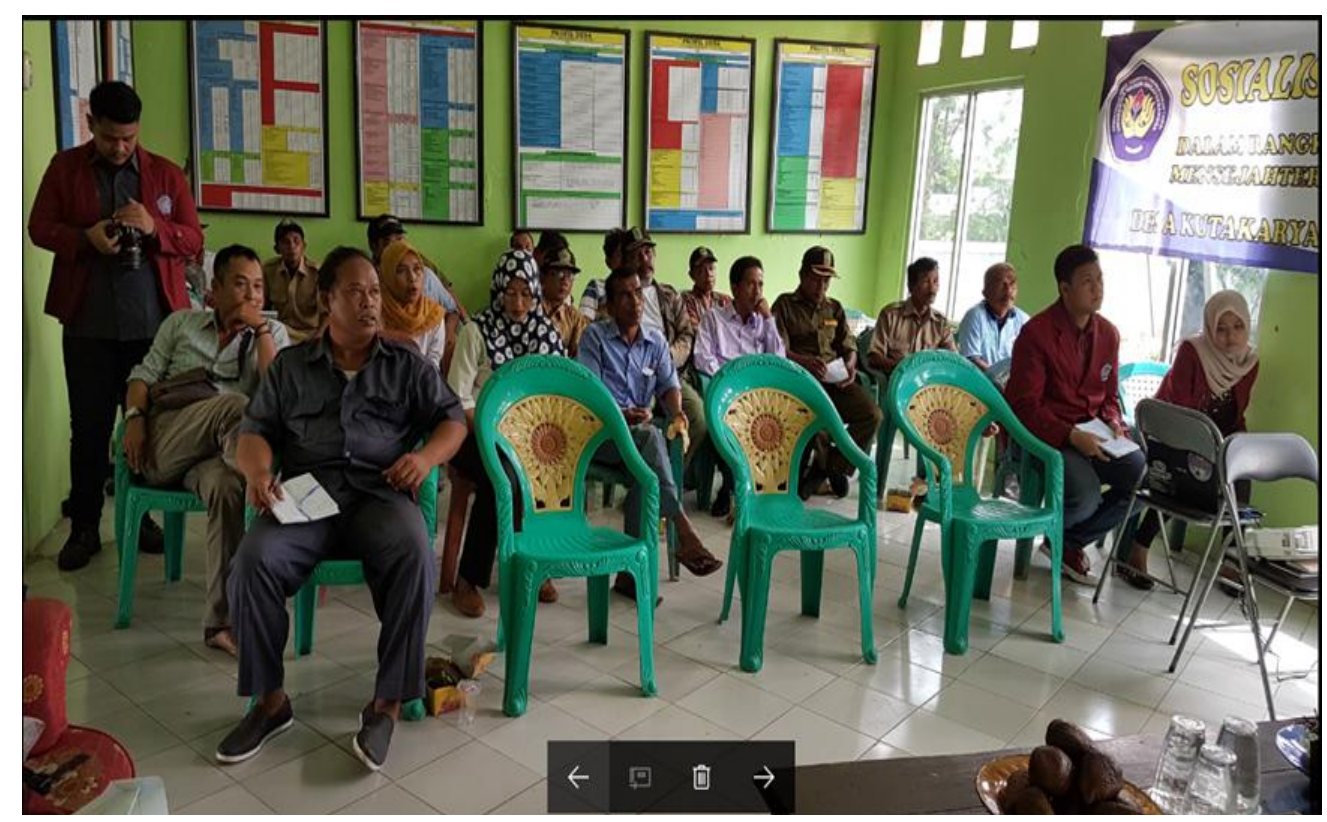

Gambar 2. Foto Kegiatan

\section{SIMPULAN}

Dalam pelaksanaan bisnis dengan skala manapun, laporan sangat penting sebagai alat bantu bagi pemilik usaha dalam pengambilan keputusan terutama untuk memperoleh gambaran kondisi kinerja keuangan perusahaan, untung atau rugi. Melalui catatan yang baik dan terus menerus akan sangat membantu mengingatkan pengusaha mengenai transaksi apa saja yang telah dilakukan perusahaan selama periode tertentu. Pemilik usaha bisa saja lupa, tapi laporan akan selalu mengingatkan setiap terjadi transaksi.

Melalui penataan laporan keuangan yang baik, diharapkan kelak para pelaku usaha kecil dan menengah tidak akan mengalami kesulitan lagi ketika akan megajukan kredit kepada pihak kreditur. Untuk itu, penyusunan laporan keuangan perlu dilakukan secara berkesinambungan dengan format pencatatan yang sederhana seperti yang telah dijelaskan dalam tulisan ini sehingga dapat ditumbuhkan kebiasaan untuk menyusun laporan keuangan pada usaha kecil dan menengah. 


\section{DAFTAR PUSTAKA}

Ihrom, 2004, Bunga Rampai Sosiologi Keluarga, Yayasan Obor Indonesia, Jakarta.

Goode, William J., 2007, Sosiologi Keluarga, Bumi Aksara, Jakarta.

Narwoko dan Bagong, 2007, Sosiologi Teks Pengantar dan Terapan, Kencana, Jakarta.

Rahardja, Pratama, Mandala Manurung, 2008, Teori Ekonomi Makro: Suatu Pengantar, Lembaga Penerbit Fakultas Ekonomi Universitas Indonesia, Jakarta.

2016, 13 Pengertian Observasi Menurut Para Ahli, diakses pada situs https://www.seputarpengetahuan.com/2015/06/13-pengertian-observasimenurut-para-ahli.html, tanggal 31 Oktober. Website: http://nasional.sindonews.com/read/1105641/18/mengapa-harus-tax-amnesty1462184213 http://pengampunanpajak.com/2016/01/21/pengamat-pesimistis-taxamnesty-mampu-dorong-penerimaan-pajak/ 